\title{
Altıncı Sınıf Öğrencilerinin Ses ve Özellikleri Ünitesi ile İlgili Başarılarını Ölçmeye Yönelik
}

\section{Bir Test Geliştirme Çalışması}

Şeyma Aksoy ${ }^{1}$, Hasan Özcan ${ }^{2}$

${ }^{1}$ Matematik ve Fen Bilimleri Eğitimi Anabilim Dal, Fen Bilimleri Enstitüsü, Aksaray Üniversitesi, Aksaray, Türkiye ${ }^{2}$ Matematik ve Fen Bilimleri Eğitimi Bölümü, Eğitim Fakültesi, Aksaray Üniversitesi, Aksaray, Türkiye

Sorumlu Yazar: Hasan Özcan, hozcan@aksaray.edu.tr

Makale Türü: Araştırma Makalesi

Bilgilendirme: Bu makale, birinci yazarın ikinci yazarın danışmanlığında tamamladığı yüksek lisans tezine dayalı olarak oluşturulmuştur.

Kaynak Gösterimi: Aksoy, Ş., \& Özcan, H. (2020). Altıncı sınıf öğrencilerinin ses ve özellikleri ünitesi ile ilgili başarılarını ölçmeye yönelik bir test geliştirme çalışması. Eğitimde Kuram ve Uygulama, 16(2), 193-214. doi: 10.17244/eku.787792

\section{Development of an Instrument for Measuring Sixth Grade Students' Understanding of Sound Concept}

$$
\text { Şeyma Aksoy', Hasan Özcan² }
$$

${ }^{I}$ Department of Mathematics and Science Education, Graduate School of Science, Aksaray University, Aksaray, Turkey ${ }^{2}$ Department of Mathematics and Science Education, Faculty of Education, Aksaray University, Aksaray, Turkey

Corresponding Author: Hasan Özcan, hozcan@aksaray.edu.tr

Article Type: Research Article

Acknowledgement: This article was generated based on the first author's master thesis prepared under the guidance of the second author.

To Cite This Article: Aksoy, Ş., \& Özcan, H. (2020). Altıncı sınıf öğrencilerinin ses ve özellikleri ünitesi ile ilgili başarılarını ölçmeye yönelik bir test geliştirme çalışması. Eğitimde Kuram ve Uygulama, 16(2), 193-214. doi: 10.17244/eku.787792 


\title{
Altıncı Sınıf Öğrencilerinin Ses ve Özellikleri Ünitesi ile İlgili Başarılarını Ölçmeye Yönelik Bir Test Geliştirme Çalışması
}

\author{
Şeyma Aksoy ${ }^{1}$, Hasan Özcan ${ }^{2}$ \\ ${ }^{1}$ Matematik ve Fen Bilimleri Eğitimi Anabilim Dall, Fen Bilimleri Enstitüsü, Aksaray Üniversitesi, Aksaray, Türkiye \\ ${ }^{2}$ Matematik ve Fen Bilimleri Ĕ̆itimi Bölümü, Eğitim Fakültesi, Aksaray Üniversitesi, Aksaray, Türkiye \\ ${ }^{1}$ ORCID: http://orcid.org/0000-0001-6464-9173 \\ ${ }^{2}$ ORCID: http://orcid.org/0000-0002-4210-7733
}

\begin{abstract}
$\ddot{\mathbf{O z}}$
Bu araştırmanın amacı altıncı sınıf "Ses ve Özellikleri” ünitesi kazanımlarını kapsayan bir akademik başarı testi geliştirmektir. Araştırmanın örneklemini 2019-2020 eğitim öğretim yılı bahar döneminde Doğu Anadolu Bölgesinde bulunan bir ilin merkez ilçesindeki iki devlet okulunda yedinci sınıfta öğrenim gören 188 öğrenci oluşturmaktadır. İki fen bilimleri alanı uzmanı ve bir fen bilimleri öğretmeninin görüşüne başvurularak ilk etapta 26 soruluk başarı testi oluşturulmuş ve testin pilot uygulaması yapılmıştır. Yapılan uygulamalar sonucunda teste 17 soruluk son hali verilmiştir. Testin son halinin uyum iyi değerleri $\chi 2 / \mathrm{df}$ : 2.097, RMSEA: 0.0059, GFI: 0.937, AGFI: 0.928 ve CFI: 0.966 olarak tespit edilmiştir. Soruların faktör yükleri ise 0.340 ile 0.719 arasında değişmektedir. Testin KR-20 iç tutarlık katsayısı 0.785 ortalama madde güçlük indeksi 0.471 ve ortalama madde ayırt edicilik indeksi ise 0.562 olarak hesaplanmıştır. Yapılan analizler sonucunda geliştirilen başarı testinin geçerli ve güvenilir olduğu saptanmıştır.
\end{abstract}

Makale Bilgisi

Anahtar kelimeler: Başarı testi, Fen bilimleri, Fen eğitimi, Ses ve özellikleri

Makale Geçmişi:

Geliş: 30 Ağustos 2020

Düzeltme: 30 Ekim 2020

Kabul: 8 Kasım 2020

Makale Türü: Araştırma Makalesi

\section{Development of an Instrument for Measuring Sixth Grade Students' Understanding of Sound}

\section{Concept}

\begin{abstract}
This research aims to develop an academic achievement test that includes the sixth-grade sound and features unit acquisitions. The sampling of the study comprises of 1887 th grade students who completed their Sound and Features unit, studying in a city center, school located in the Eastern Anatolia Region in Turkey for the 2019-2020 academic year. In the first step, an achievement test of 26 questions was created by referring to the opinions of two science experts and a science teacher, and the test was piloted. As a result of the applications, the test was finalized with 17 questions. Good fit values of the final test were determined as $\chi 2$ / df: 2.097, RMSEA: 0.0059, GFI: 0.937, AGFI: 0.928 and CFI: 0.966. The factor loadings of the questions vary between 0.340 and 0.719 . The KR-20 internal consistency coefficient of the test was 0.785 , the average item difficulty index was 0.471 , and the average item discrimination index was 0.562 . The achievement test developed as a result of the analysis was found to be valid and reliable.
\end{abstract}

\begin{abstract}
Article Info
Keywords: Achievement test, Science, Science education, Sound and features
\end{abstract}

\section{Article History:}

Received: 30 August 2020

Revised: 30 September 2020

Accepted: 8 October 2020

Article Type: Research Article 


\section{Extended Summary}

\section{Introduction}

In terms of understanding the functioning of the universe and nature, there are important roles in science teaching. Since the early 1900s, many researchers have been researching student concepts related to various phenomena. These researchers state that student concepts are consistent with scientific knowledge and sometimes inconsistent. As one of the reasons for these inconsistent situations, it can be shown that some subjects in science have an abstract nature, especially the primary and secondary school-age children cannot construct the relevant subject concepts in a meaningful way. Sound and its features have an abstract feature as mentioned. Because although it is a subject that is intertwined with daily life, how sound is formed, how it spreads, its situation in space and its microscopic scale explanations remain abstract for students. Therefore, they have difficulties in structuring information. For example, students confuse the formation and propagation of sound, thinking that it travels in an airless environment and stops when it hits an obstacle. For the reasons stated, teaching the subject of sound and its features have been the subject of research for many researchers.

As a result of the literature review, an achievement test for sixth-grade students, which covers only the phoneme acquisitions and is compatible with the 2018 Science Curriculum, could not be detected. For this reason, this study, it is aimed to develop a valid and reliable achievement test that can be used to measure the success of sixth-grade students in the sound and characteristics unit by following the test development process steps.

Within the aim of this purpose, answers to the following questions were sought.

1. What is the construct validity of the achievement test developed?

2. What is the item discrimination and difficulty index value of each multiple-choice problem in the developed achievement test?

3. What is the reliability coefficient $(\mathrm{KR}-20)$ of the data obtained from the developed success test?

\section{Method}

In this study, the achievements of the Science Curriculum were taken as a basis and the questions connected to the related outcomes were determined from the exams conducted by the Ministry of National Education at various times. The determined questions were presented to expert opinion first and then a pilot application was carried out with 24 students studying in the sixth grade. Then, the actual application was carried out with 188 students and the necessary validity, reliability, and item analysis were carried out.

The sample of the study consists of 188 seventh grade students studying at two different secondary schools in a city center in the Eastern Anatolia Region in the 2019-2020 academic year. 89 of these students are male and 99 are female. Students generally have a medium socioeconomic level.

\section{Findings}

The findings obtained while developing the achievement test were discussed in line with the sub-problems. In the first sub-problem, the construct validity of the test was investigated. In this direction, Tetrachoric Factor Analysis was performed, and it was determined that the factor loads of the items in the test varied between 0.340 and 0.719 .

While developing the test in line with the second sub-problem, the item difficulty and discrimination indexes of each item were calculated. As a result of the first analysis, it was seen that the item difficulty indexes of the items in the test took values between 0.18 and 0.70 , and the item discrimination indexes varying between -0.03 and 0.69 . As a result of the analyzes performed after the items were removed, it was observed that the item difficulty indexes of the items in the test took values between 0.30 and 0.69 , and the item discrimination indexes varying between 0.36 and 0.72 .

As a result of the item analysis performed to reveal the reliability of the test in line with the third sub-problem, it is seen that the KR-20 value of the final version of the test is .785. Also, the average item discrimination index was .562 and the average item difficulty index was .471.

\section{Discussion and Conclusion}

The calculated KR-20 reliability coefficient of the developed test was determined as 0.785 . Since this value is between 0.60 and 0.90 , it reveals that the results of the test are reliable. When the literature is examined, it is seen that the reliability coefficients of the measurement tools put forward for the relevant subject are close to each other with the reliability coefficients revealed in this study. As an example of this situation, the reliability coefficient of the test developed by Akarsu (2015) to measure the concept level knowledge of eighth-grade students about the sound unit (0.72) and the reliability coefficient of the successful test in the study conducted by Evrekli, İnel, and Balım (2012) on the sixth-grade light and sound unit (0.80) can be given. It is recommended to use this developed achievement test both for evaluation at the end of the unit and for examining the prior knowledge of students at a higher education level. Also, it is recommended to develop tests that can reveal the conceptual understanding of students based on the strong distractors revealed by the analysis made for each item in the development process of the test. 


\section{Giriş}

Evrenin ve doğanın işleyişini kavrayabilme hususunda fen bilimleri öğretimi üzerine önemli roller düşmektedir. 1900'lü yılların başından beridir pek çok araştırmacı çeşitli fenomenler ile ilgili öğrenci kavramlarını araştırmaktadır. Bu araştırmacılar öğrenci kavramlarının bilimsel bilgi ile tutarlı olduğunu bazı durumlarda ise tutarsız olduğunu belirtmektedir (Caleon \& Subramaniam, 2010). Bu tutarsız durumların sebeplerinden biri olarak fen bilimlerindeki bazı konuların soyut bir doğaya sahip olması nedeniyle özellikle ilkokul ve ortaokul çağındaki çocukların ilgili konu kavramlarını anlamlı bir şekilde yapılandıramaması gösterilebilir. Ses ve özellikleri konusu da belirtildiği gibi soyut bir özelliğe sahiptir. Her ne kadar günlük yaşamla iç içe bir konu olsa da sesin nasıl oluştuğu, nasıl yayıldığı, boşluktaki durumu ve mikroskobik ölçekli açıklamaları öğrenciler için soyut kalmaktadır. Dolayısıyla bilgiyi yapılandırma hususunda güçlükler çekmektedirler. Örneğin, öğrenciler sesin oluşumunu ve yayılmasını karıştırmakta, havasız ortamda ilerlediğini ve bir engele çarptığında durduğunu düşünmektedirler (Demirci \& Efe, 2007). Belirtilen nedenlerden dolayı ses ve özellikleri konusu öğretimi pek çok araştırmacının araştırma konusu olmuştur.

Araştırmacılar ulusal ve uluslararası düzeyde ses ve özellikleri ile ilgili;

- kavram yanılgıları (örn: Dinçer \& Özcan, 2016; Eshach, Lin, \& Tsai, 2018; Kistak, 2014; Pejuan, Bohigas, Jaén, \& Periago, 2012; Sözen \& Bolat, 2014; Wild, Hilson, \& Hobson, 2013),

- çeşitli yöntem ve tekniklere göre öğretim (örn: Aydın \& Kömürkaraoğlu, 2016; Hrepic, Nettles, \& Bonilla, 2013; Iliaki, Velentzas, Michailidi, \& Stavrou 2019; Şenel-Çoruhlu, Er-Nas \& Keleş, 2016; West \& Wallin, 2013),

- bireylerin zihinlerinde ses ve sesin özelliklerinin modellenmesi (örn: Hrepic, Zollman, \& Rebello, 2010; Yüzbaşığlu, 2015),

- öğrencilerin kavramsal anlamaları (örn: Eshach, 2014; Gunhaart, \& Srisawasdi, 2012),

- kavramsal değişimlerin sağlanması (örn: Calik, Okur, \& Taylor, 2011; Eshach, Lin, \& Tsai, 2018),

- ses ve özelliklerinin nasıl temsil edildikleri (örn: Calderon-Canales, Gallegos-Cazares, \& Flores-Camacho, 2019) ve

- ses ile ilgili edinilen ön kavramlar (örn: Hernández, Couso, \& Pintó, 2012) üzerine araştırmalar yürütmüşlerdir.

Yapılan bu çalışmaların altında yatan temel amaçlardan birisi öğrencilerin anlamlı öğrenmelerini sağlayarak onların başarısını üst noktalara taşıyabilmektir. Bu hususta öğretmenlere de pek çok görev düşmektedir. Bu görevlerden bazılarının akademik başarıdaki değişimleri gözlemlemek, analiz etmek ve anlamlı öğrenme için gerekli tedbirleri almak olduğu belirtilebilir (Bell \& Cowie, 2002; Özcan, Koca, \& Söğüt, 2019). Bu sürecin gerçekleştirilebilmesi için ölçme ve değerlendirmenin önemli bir unsur olduğu ifade edilebilir. Ölçme ve değerlendirme süreciyle öğrencilerin kazanmış oldukları bilgi ve beceriler saptanabilmekte, öğrencilerdeki eksik kazanımlar öğretmenler tarafından fark edilebilmekte (Metin, 2013) ve bireyin akademik geleceği hakkında sağlıklı kararlar verilebilmektedir (Akarsu, 2018). Bu yüzdendir ki öğretmenlerin öğrencilerdeki gelişimi takip edebilmek için uygun ölçme ve değerlendirmenin nasıl yapılabileceğini bilmeleri gerekmektedir (Korkmaz \& Kaptan, 2005; Newfields, 2006).

Ölçme değerlendirme sistemi içerisinde objektif puanlamaya olanak tanıması, çok sayıda kişiye kısa sürede sınav yapılabilmesi, farklı bilgi ve beceri türlerini ölçebilmesi, çok sayıda soru sorularak kapsam geçerliği ve test puanlarının güvenirliğini artırabilmesi ve puanlamanın kolay ve kısa sürede yapılabilmesi özelliklerinden (Tekindal, 2017) dolayı günümüzde öğretim ile ilgili kararlar almada çoktan seçmeli testler sıklıkla kullanılmaktadır (Katz \& Slomka, 1999). $\mathrm{Bu}$ duruma paralel olarak ulusal ve uluslararası alanyazında fen bilimleri eğitimine pek çok konuda araştırmacılar tarafından geliştirilmiş farklı konu ve kazanımlarına yönelik geliştirilmiş birçok çoktan seçmeli akademik başarı testi bulunmaktadır (örn: Çalık \& Ayas, 2003; Lin, 2004; Şen \& Eryılmaz, 2011; Romine, Schaffer, \& Barrow, 2015). Geliştirilmiş olan başarı testleri incelendiğinde ses ve özellikleri ünitesine yönelik testlerin de geliştirildiği görülmektedir. Bu çalışmalar Tablo 1'de sunulmaktadır.

Tüm bu çalışmalar incelendiğinde altıncı sınıf öğrencilerine yönelik başarı testlerinin sşık ünitesi ile birlikte ele alındığı görülmektedir. Ulusal alanyazında bu durumun sebebi olarak gerçekleştirilmiş olan çalışmaların 2018 Fen Bilimleri Öğretim Programı öncesinde yürürlükteki Fen Bilimleri Öğretim Programlarına göre hazırlanmış olmaları gösterilebilir. Örneğin 2013 programında altıncı sınıf seviyesinde 1şık ve ses konusu bir ünite olarak ele alınmış ve sese yönelik üç kazanım ifade edilmiştir. Günümüz öğretim programında ise altıncı sınıf seviyesinde tek başına dört bölümden oluşan bir ünite olarak sunulmuş ve toplam dokuz kazanım belirtilmiştir. Tablo 1'deki çalışmalar arasında her ne kadar Yanar, Saylan-Kırmızıgül ve Kaya (2019) tarafından yürütülen çalışma 2018 sonrası olarak görülüp 2018 Fen Bilimleri Öğretim Programına göre olduğu izlenimi oluştursa da araştırmacılar 2013 Fen Bilimleri Öğretim Programına göre başarı testlerini oluşturmuşlardır. Dolayısıyla geliştirdikleri başarı testi hem 1şık hem de ses kazanımlarını içermektedir. Yapılan alanyazın taraması neticesinde sadece ses ünitesi kazanımlarını kapsayan ve 2018 Fen Bilimleri Öğretim Programıyla uyumlu altıncı sınıf öğrencilerine yönelik bir başarı testi tespit edilememiştir. 
Tablo 1. Ses konusu ile ilgili yapılan çalışmalarda kullanılan başarı testleri

\begin{tabular}{|c|c|c|c|}
\hline Araştırmacı(lar) & Sinıf seviyesi & Konu & Yil \\
\hline Demirci \& Efe & 5. sinif & Ses & 2007 \\
\hline Salgut & 5.sinif & Iş1k ve ses & 2007 \\
\hline Tok & 5.sinif & Iş1k ve ses & 2008 \\
\hline Yurd \& Olğun & 5.sinif & Iş1k ve ses & 2008 \\
\hline Caleon \& Subramaniam & 10. sinif & Ses, 1şık ve su dalgaları (Ana odak ses dalgaları) & 2009 \\
\hline Büyükkara & 8.sinif & Ses & 2011 \\
\hline Evrekli, İnel, \& Balım & 6.sinif & Iş1k ve ses & 2012 \\
\hline Sözen \& Bolat & İlköğretim ve ortaöğretim öğrencileri & Ses & 2014 \\
\hline Akarsu & 8. sinif & Ses & 2015 \\
\hline Bakırcı, Çepni, \& Yıldız & 6.sinif & Iş1k ve ses & 2015 \\
\hline Yilmaz & 8.sinif & Ses & 2015 \\
\hline Teker & 5.sinif & Iş1k ve ses & 2015 \\
\hline Şenel-Çoruhlu, Er-Nas, \& Keleş & 6.sinif & Iş1k ve ses & 2016 \\
\hline Aydın \& Kömürkaraoğlu & 6.sinif & Iş1k ve ses & 2016 \\
\hline Y1lmaz & 5.sinif & Iş1k ve ses & 2016 \\
\hline Yazıcı̆ı̆lu & 6.sinif & Iş1k ve ses & 2017 \\
\hline Aytekin & 5.sinif & Iş1k ve ses & 2018 \\
\hline Volfson, Eshach, \& Ben-Abu & Üniversite fizik ve mühendislik öğrencileri & Ses & 2018 \\
\hline Yanar, Saylan-Kırmızıgül, \& Kaya & 6. $\sin 1 f$ & Iş1k ve ses & 2019 \\
\hline
\end{tabular}

Bu sebepten dolayı bu çalışmada test geliştirme süreci basamakları takip edilerek altıncı sınıf öğrencilerinin ses ve özellikleri ünitesindeki başarılarını ölçmek için kullanılabilecek geçerli ve güvenilir bir başarı testi geliştirmek amaçlanmıştır.

$\mathrm{Bu}$ amaç kapsamında aşağıda belirtilen sorulara yanıt aranmıştır.

1. Geliştirilen başarı testinin yapı geçerliği durumu nedir?

2. Geliştirilen başarı testinin kapsam geçerliği durumu nedir?

3. Geliştirilen başarı testindeki çoktan seçmeli her bir sorunun madde ayırt edicilik ve güçlük indeksi değeri nedir?

4. Geliştirilen başarı testinden elde edilen verilerin güvenirlik katsayısı (KR-20) nedir?

\section{Yöntem}

Bu çalışmada, ortaokul altıncı sınıf öğrencilerinin ses ve özellikleri ünitesine yönelik akademik başarılarını ölçmek amacıyla bir başarı testi geliştirilip geçerlik ve güvenirlik hususları üzerine incelemeler gerçekleştirilmiştir. Üniteye ait kazanımlarda MEB (2018) Fen Bilimleri Öğretim Programı kazanımları esas alınmış ve çeşitli zamanlarda MEB tarafindan gerçekleştirilmiş olan sınavlardan, ilgili kazanımlara yönelik olan sorular tespit edilmiştir. Belirlenen sorular önce uzman görüşüne sunulmuş sonrasında altınc1 sınıfta öğrenim görmekte olan 24 öğrenci ile pilot uygulaması gerçekleştirilmiştir. Ardından 188 öğrenci ile asıl uygulaması gerçekleştirilerek gerekli geçerlik, güvenirlik ve madde analizleri gerçekleştirilmiştir. Bu çalışmada, veri toplama sürecine geçilmeden Aksaray Üniversitesi Etik Komisyonu'ndan 19.04.2019 tarih ve 2019/03-17 sayılı etik onay alınmıştır.

\section{Örneklem}

Örneklem seçilirken amaçlı örnekleme yöntemlerinden biri olan uygun örnekleme yöntemi kullanılmıştır. Uygun örnekleme yönteminde araştırmacıları zaman, maliyet, uygulama kolaylığı gibi unsurları göz önünde bulundurarak örneklemlerini seçmektedirler (Fraenkel, Wallen, \& Hyun, 2012). Çalışmanın örneklemini 2019-2020 eğitim öğretim y11ı içerisinde Doğu Anadolu Bölgesinde yer alan bir şehir merkezinin iki farklı ortaokulunda öğrenim görmekte olan 188 yedinci sınıf öğrencisi oluşturmaktadır. Bu öğrencilerin 89’u erkek, 99'u ise kızdır. Öğrenciler genel olarak orta sosyo-ekonomik düzeye sahiptirler.

\section{Ses ve Özellikleri Başarı Testinin Geliştirilme Süreci}

Ses ve Özellikleri Başarı Testi (SÖBT), araştırmacılar tarafından ortaokul altıncı sınıf öğrencilerinin ilgili konudaki akademik başarılarını değerlendirmek amacıyla geliştirilmiştir. Ses ve özellikleri ünitesi sesin yayılması, sesin farklı ortamlarda farklı duyulması, sesin sürati, sesin maddeyle etkileşmesi bölümlerini içermektedir. SÖBT hazırlanırken belirtilen bölüm kazanımlarına yönelik soru havuzu, MEB tarafından gerçekleştirilmiş olan Seviye Belirleme Sınavı (SBS), Devlet Parasız Yatılı1ık ve Bursluluk Sinavı (PBYS), Merkezi Ortak Sinav (MOS), Ortak Sinav (OS) ve Bursluluk Sınavı (BS) sorularından seçilerek oluşturulmuştur. 2018 Fen Bilimleri Öğretim Programı öncesindeki programlarda ses konusu altıncı sınıflarda 1şık ile birlikte bir ünite olarak ele alınmış olduğundan soruların seçiminde sadece ses içeriğinin olması ve Tablo 2'de belirtilen kazanımlara yönelik olması kriter olarak ele alınmıştır. Soruların belirlenmesinin ardından iki fen bilgisi alan uzmanı ve bir fen bilgisi öğretmeni tarafından kapsam geçerliği doğrultusunda görüşleri alınmıştır. Uzmanların mesleki deneyimleri 10 yılın üzerinde olup fen eğitimi alanında pek çok çalışmaları bulunmaktadır. Öğretmenin ise mesleki deneyimi 11 yıldır. Uzmanların ve öğretmenin görüşleri alınırken 
kazanım ilgili soru sunulmuş ve sorunun ilgili kazanımı temsil edip etmediği sorgulanmıştır. Uzmanlar ile öğretmenden gelen dönütler doğrultusunda altıncı sınıf ses ve özellikleri ünitesi kazanımlarıyla uyuşmayan sorular soru havuzundan çıkartılmıştır. Geriye toplamda 26 soru kalmıştır. Belirlenen sorular ve ilgili oldukları kazanımlar Tablo 2'de sunulmuştur ayrıca Ek-1'de yenilenen Bloom taksonomisine göre belirtke tablosu yer almaktadır.

Tablo 2. 2018 fen bilimleri öğretim programı ses ve özellikleri ünite kazanımları ve ilişkili sorular

\begin{tabular}{|c|c|}
\hline Kazanım & Soru numaraları \\
\hline F.6.5.1.1. Sesin yayılabildiği ortamları tahmin eder ve tahminlerini test eder. & $\begin{array}{l}1 \text { (PYBS-2010), } 3 \text { (PYBS-2013), } \\
14 \text { (MOS-2017), Ç1kartılan-4+(PYBS-2012) }\end{array}$ \\
\hline F.6.5.2.1. Ses kaynağının değişmesiyle seslerin farklı işitildiğini deneyerek keşfeder. & $5($ PYBS-2014) \\
\hline $\begin{array}{l}\text { F.6.5.2.2. Sesin yayıldığı ortamın değişmesiyle farklı işitildiğini deneyerek keşfeder. } \\
\text { Frekans kavramına girilmez. }\end{array}$ & 10 (PYBS-2016) \\
\hline $\begin{array}{l}\text { F.6.5.3.1. Sesin farklı ortamlardaki süratini karşılaştırır. } \\
\text { a. Sesin boşlukta neden yayılmadı̆̆ belirtilir. } \\
\text { b. Işı ve sesin havadaki sürati; şimşek, yıldırım ve gök gürültüsü olayları üzerinden } \\
\text { karşılaştırılır. } \\
\text { c. Sesin bir enerji türü olduğuna değinilir. }\end{array}$ & $\begin{array}{l}2 \text { (SBS-2012), } 4 \text { (OS-2014), } \\
6 \text { (MOS-2015), } 7 \text { (MOS-2015), } \\
9 \text { (MOS-2016), } 12 \text { (MOS-2017), } \\
\text { Ç1kartılan-1 }{ }^{+} \text {(SBS-2009) } \\
\text { Ç1kartılan-3 }{ }^{+} \text {(SBS-2010) } \\
\text { Çıkartılan-5 } 5^{+} \text {(OS-2014-2018) } \\
\text { Çıartılan-7 } 7^{+} \text {(MOS-2016) } \\
\text { Çıkartılan- } 8^{+} \text {(BS-2018) }\end{array}$ \\
\hline F.6.5.4.1. Sesin yansıma ve soğurulmasına örnekler verir. & $\begin{array}{l}11 \text { (PYBS-2016), } 17 \text { (PYBS-2012), } \\
\text { Cikart1lan-2 } \\
\text { (SBS-2010) }\end{array}$ \\
\hline $\begin{array}{l}\text { F.6.5.4.2. Sesin yayılmasını önlemeye yönelik tahminlerde bulunur ve tahminlerini test } \\
\text { eder. }\end{array}$ & Ç1kartılan-6 ${ }^{+}($PYBS-2015) \\
\hline $\begin{array}{l}\text { F.6.5.4.3. Ses yalıtımının önemini açıklar. } \\
\text { Ses yalıtımı için gelisstirilen teknolojik ve mimari uygulamalara değinilir. }\end{array}$ & $\begin{array}{l}8 \text { (PYBS-2015), } 13 \text { (PYBS-2017), } 15 \text { (PYBS- } \\
2018)\end{array}$ \\
\hline $\begin{array}{l}\text { F.6.5.4.4. Akustik uygulamalarına örnekler verir. } \\
\text { Modern ve kültürel mimarideki uygulamalara vurgu yapılır. } \\
\text { Örneğin Süleymaniye Camii’nin akustik mimarisine atıf yapılır. }\end{array}$ & $\begin{array}{l}16(\text { PYBS-2014), } \\
\text { Çıkartılan-9+ } 9^{+} \text {(PYBS-2013) }\end{array}$ \\
\hline
\end{tabular}

${ }^{+}$Testin geliştirilme sürecinde yapılan analizler neticesinde testten çıkartılmış maddeleri temsil etmektedir. Testin son haline gelene kadar her bir maddedeki değişimin okuyucu tarafından görülebilmesi için isimlendirilmiştir.

Not: PYBS: Devlet Parasız Yatılı Bursluluk Sinavı, SBS: Seviye belirleme Sınavı, MOS: Merkezi Ortak Sinav, OS: Ortak Sinav, BS: Bursluluk Sinav1

Soru havuzundaki soruların tamamı görünüş geçerliği sağlanacak şekilde öğrencilere uygulanabilecek bir test haline getirilmiştir. Bu testte yer alan 1, 7, 13, 14 ve çıartılan 9. soru yenilenen Bloom taksonomisine (Anderson et al., 2001) göre olgusal bilgi-hatırlama türünde 3 . soru kavramsal bilgi-hatırlama türünde 2, 4, 5, 6, 8, 9, 10, 11, 12, 15, $16,17$. çıkartılan 1-2-4-5-6-7-8. kavramsal bilgi-anlama düzeyinde ve son olarak çıkartılan-3. soru kavramsal bilgi-çözümle türündedir (Belirtke tablosu Ek-1'de yer almaktadır). Bu testin öncelikle 24 altıncı sınıf öğrencisi ile pilot uygulaması gerçekleştirilmiştir. Pilot uygulama gerçekleştirilirken bir ders saati süresi kullanılmıştır. Testin sonuçlarının öğrenciler için herhangi bir değerlendirme durumunda not verme amacıyla kullanılmayacağı hem pilot uygulamada hem de asıl uygulamada belirtilmiştir. Pilot uygulama sürecinde, herhangi bir problemle karşılaşılmaması üzerine yedinci sınıfta öğrenim gören toplam 188 öğrenci ile asıl uygulaması gerçekleştirilerek gerekli geçerlik, güvenirlik ve madde analizleri gerçekleştirilmiştir. Analizler gerçekleştirilirken yapı geçerliği için $\chi 2$ df, RMSEA, GFI, AGFI, CFI değerleri ve her bir maddenin faktör yükü Tetrakorik Faktör Analizi ile hesaplanmıştır. Ayrıca geliştirilen testin ortalama, standart sapma, basıklık, çarpıklık, KR-20, ortalama madde güçlüğü ve ortalama madde ayırt ediciliği değerleri TAP (Test Analysis Program) kullanılarak ortaya konulmuştur.

\section{Bulgular}

SÖBT geliştirilirken elde edilen bulgular alt problemler doğrultusunda ele alınmıştır. Birinci alt problemde testin yapı geçerliği araştırılmıştır. Bu doğrultuda Tetrakorik Faktör Analizi gerçekleştirilmiştir. Analiz gerçekleştirilmeden önce verilerin faktör analizine uygun olup olmadığını değerlendirmek için Bartlett küresellik testi sonucu ve Kaiser Meyer Olkin (KMO) değerine bakılmıştır. Bartlett küresellik testi sonucu $(\mathrm{p}<.05)$ anlamlı farklılık göstermekte olup verilerin normal dağıldığını ortaya koymaktadır. KMO değeri ise .628 değerinde olup veri büyüklüğünün asgari düzeyde sağlandığını göstermektedir. Bunun nedeni KMO değerinin, verilerin faktör çıkartmaya uygunluğunun bir göstergesi olması ve en az 0.60 üzerinde olmasının beklenmesidir (Büyüköztürk, 2018). Faktör analizi için gerekli koşulların sağlandığ 1 tespit edildikten sonra gerekli analizler gerçekleştirilmiştir. Analizler neticesinde Tablo 3 'te sunulan uyum iyiliği değerleri elde edilmiştir. 
Tablo 3. SÖBT’nin yapı geçerliği için uyum iyiliği değerleri

\begin{tabular}{lcc}
\hline \multicolumn{1}{c}{ Uyum iyiliği göstergesi } & İlk Analiz Değeri & Son Analiz Değeri \\
\hline Ki kare / serbestlik derecesi ( $\chi 2 /$ df) & $662.598 / 299=2.216$ & $249.642 / 119=2.097$ \\
Root Mean Square Error of Approximation (RMSEA) & 0.053 & 0.059 \\
Goodness of Fit Index (GFI) & 0.887 & 0.937 \\
Adjusted Goodness of Fit Index (AGFI) & 0.878 & 0.928 \\
Comparative Fit Index (CFI) & 0.950 & 0.966 \\
\hline
\end{tabular}

SÖBT'nin yukarıda belirtilen uyum iyiliği değerleri elde edilirken her bir maddenin faktör yükü Tablo 4'te belirtildiği gibi hesaplanmıştır. Yapı geçerliğinin sağlanması sürecinde hem uyum iyiliği değerleri hem faktör yükleri hem de madde güçlük ve ayırt edicilik indeksleri göz önünde bulundurulmuştur. Bundan dolayı testten bazı maddeler çıkartılmıştır. Maddeler çıkartılırken bazı durumlarda faktör yükünün istenilen aralıkta çıkmaması bazı durumlarda ise madde güçlük ve ayırt edicilik indekslerinin istenilen aralıkta çıkmaması etkili olmuştur.

Tablo 4. SÖBT'nin geliştirilme sürecindeki madde faktör yükleri

\begin{tabular}{cccccc}
\hline Madde & İlk Analiz Faktör Yükü & Son Analiz Faktör Yükü & Madde & İk Analiz Faktör Yükü & Son Analiz Faktör Yükü \\
\hline 1 & -0.519 & 0.562 & 14 & -0.670 & 0.697 \\
2 & -0.472 & 0.477 & 15 & -0.620 & 0.605 \\
3 & -0.599 & 0.644 & 16 & -0.540 & 0.517 \\
4 & -0.483 & 0.472 & 17 & -0.368 & 0.369 \\
5 & -0.512 & 0.511 & $C ̧ 1$ & $\mathbf{0 . 2 8 3}$ & \\
6 & -0.583 & 0.584 & Ç2 & $\mathbf{- 0 . 2 6 2}$ & $\mathbf{0 . 2 1 8}$ \\
7 & -0.452 & 0.453 & $C ̧ 3$ & 0.473 & \\
8 & -0.328 & 0.340 & Ç4 & $\mathbf{- 0 . 2 5 3}$ & \\
9 & -0.542 & 0.541 & Ç5 & $\mathbf{- 0 . 2 5 9}$ & \\
10 & -0.732 & 0.719 & $\mathbf{0 . 1 8 8}$ & \\
11 & -0.410 & 0.377 & $C ̧ 8$ & $\mathbf{0 . 1 5 5}$ & \\
12 & -0.644 & 0.647 & $\mathbf{- 0 . 2 2 1}$ & \\
13 & -0.527 & 0.471 & &
\end{tabular}

Tablo 4'te görüldüğü gibi Ç1-2-3-5-6-7-8-9 olarak adlandırılan soruların faktör yükleri 0.30'un altındadır. Bu durum ilgili maddelerin yapıyı iyi ölçmediğinin bir göstergesi olarak yorumlanmaktadır (Kline, 1994). Ayrıca Ç4 maddesinin faktör yükü kabul edilebilir bir değer iken Tablo 5 'te gösterildiği gibi madde güçlük indeksi 0.18 ve madde ayırt edicilik indeksi -0.12 olarak tespit edilmiștir. Bu sebepten dolayı CC1-9 olarak isimlendirilen maddelerin tamamı ölçekten çıkartılmıştır. Son durumda testte yer alan maddelerin faktör yükleri 0.340 ile 0.719 arasında değişmektedir.

İkinci alt problem doğrultusunda SÖBT geliştirilirken bünyesinde bulunan her bir maddenin madde güçlük, ayırt edicilik indeksleri hesaplanmıştır. Tespit edilen indeksler Tablo 5 'te sunulmuştur.

Tablo 5 incelendiğinde testin son halinin KR-20 değerinin .785 olduğu görülmektedir. Bunun yanı sira ortalama madde ayırt edicilik indeksi .562 ortalama madde güçlük indeksi ise .471 olarak tespit edilmiştir.

Tablo 5. SÖBT’nin geliştirme sürecindeki madde güçlük ve madde ayırt edicilik indeksleri

\begin{tabular}{|c|c|c|c|c|c|c|c|c|c|c|c|c|c|c|}
\hline \multirow[b]{2}{*}{$\frac{\stackrel{0}{\frac{0}{0}}}{\sum}$} & \multicolumn{7}{|c|}{ İlk Analiz } & \multicolumn{7}{|c|}{ Son Analiz } \\
\hline & Grup & $\mathbf{A}$ & B & C & D & 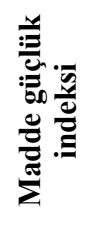 & 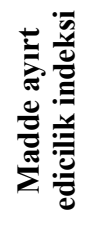 & Grup & $\mathbf{A}$ & B & C & D & 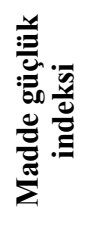 & 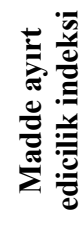 \\
\hline \multirow{3}{*}{1} & Toplam & 24 & 56 & $99 *$ & 9 & \multirow{4}{*}{0.53} & \multirow{3}{*}{0.55} & Toplam & 24 & 56 & $99^{*}$ & 9 & \multirow{3}{*}{0.53} & \multirow{3}{*}{0.64} \\
\hline & Üst & 5 & 9 & 46 & 1 & & & Üst & 3 & 6 & 42 & 0 & & \\
\hline & Alt & 15 & 25 & 11 & 3 & & & Alt & 13 & 31 & 11 & 4 & & \\
\hline \multirow{3}{*}{2} & Toplam & $91 *$ & 35 & 36 & 22 & & \multirow{3}{*}{0.52} & Toplam & $91^{*}$ & 35 & 36 & 22 & \multirow{3}{*}{0.48} & \multirow{3}{*}{0.60} \\
\hline & Üst & 45 & 7 & 6 & 2 & \multirow[t]{2}{*}{0.48} & & Üst & 40 & 5 & 4 & 1 & & \\
\hline & Alt & 12 & 14 & 14 & 12 & & & Alt & 11 & 17 & 17 & 13 & & \\
\hline \multirow{3}{*}{3} & Toplam & 34 & $116^{*}$ & 28 & 10 & \multirow{3}{*}{0.62} & \multirow{3}{*}{0.61} & Toplam & 34 & $116^{*}$ & 28 & 10 & \multirow{3}{*}{0.62} & \multirow{3}{*}{0.67} \\
\hline & Üst & 5 & 54 & 1 & 1 & & & Üst & 1 & 48 & 1 & 1 & & \\
\hline & Alt & 21 & 15 & 11 & 7 & & & Alt & 20 & 16 & 17 & 6 & & \\
\hline \multirow{3}{*}{4} & Toplam & 38 & 40 & 19 & $89 *$ & \multirow{3}{*}{0.47} & \multirow{3}{*}{0.48} & Toplam & 38 & 40 & 19 & $89 *$ & \multirow{3}{*}{0.47} & \multirow{3}{*}{0.58} \\
\hline & Üst & 6 & 7 & 4 & 44 & & & Üst & 4 & 6 & 1 & 40 & & \\
\hline & Alt & 12 & 18 & 11 & 13 & & & Alt & 16 & 19 & 12 & 12 & & \\
\hline \multirow[t]{3}{*}{5} & Toplam & $130^{*}$ & 24 & 17 & 17 & \multirow{3}{*}{0.69} & \multirow{2}{*}{0.49} & Toplam & $130 *$ & 24 & 17 & 17 & \multirow{3}{*}{0.69} & \multirow{3}{*}{0.53} \\
\hline & Üst & 55 & 4 & 1 & 1 & & & Üst & 47 & 3 & 1 & 0 & & \\
\hline & & & & & & & 198 & & & & & & & \\
\hline
\end{tabular}


Eğitimde Kuram ve Uygulama, 16(2), 193-214

\begin{tabular}{|c|c|c|c|c|c|c|c|c|c|c|c|c|c|c|}
\hline \multirow{4}{*}{6} & Alt & 22 & 11 & 9 & 12 & & & Alt & 16 & 19 & 12 & 12 & & \\
\hline & Toplam & $59 *$ & 60 & 30 & 37 & \multirow{3}{*}{0.31} & \multirow{3}{*}{0.46} & Toplam & $59 *$ & 60 & 30 & 37 & \multirow{3}{*}{0.31} & \multirow{3}{*}{0.55} \\
\hline & Üst & 37 & 14 & 2 & 7 & & & Üst & 33 & 11 & 0 & 6 & & \\
\hline & Alt & 8 & 20 & 15 & 11 & & & Alt & 6 & 24 & 16 & 13 & & \\
\hline \multirow{3}{*}{7} & Toplam & 61 & $58^{*}$ & 30 & 39 & \multirow{3}{*}{0.31} & \multirow{3}{*}{0.39} & Toplam & 61 & $58^{*}$ & 30 & 39 & \multirow{3}{*}{0.31} & \multirow{3}{*}{0.47} \\
\hline & Üst & 19 & 32 & 4 & 6 & & & $\ddot{U} s t$ & 13 & 29 & 3 & 6 & & \\
\hline & Alt & 15 & 7 & 15 & 17 & & & Alt & 20 & 6 & 14 & 19 & & \\
\hline 8 & Toplam & 22 & 36 & 63 & $65^{*}$ & & & Toplam & 22 & 36 & 63 & $65^{*}$ & & \\
\hline 8 & Üst & 4 & 3 & 24 & 30 & 0.35 & 0.27 & Üst & 4 & 3 & 16 & 28 & 0.35 & 0.36 \\
\hline & Alt & 12 & 15 & 13 & 12 & & & Alt & 11 & 18 & 17 & 11 & & \\
\hline 0 & Toplam & 39 & $85^{*}$ & 25 & 37 & & & Toplam & 39 & $85^{*}$ & 25 & 37 & & \\
\hline 3 & Üst & 6 & 49 & 2 & 4 & 0.45 & 0.53 & Üst & 4 & 44 & 1 & 2 & 0.45 & 0.57 \\
\hline & Alt & 10 & 15 & 15 & 12 & & & Alt & 11 & 17 & 16 & 13 & & \\
\hline 10 & Toplam & 17 & 26 & $117^{*}$ & 24 & & & Toplam & 17 & 26 & $117 *$ & 24 & & \\
\hline 10 & Üst & 1 & 1 & 58 & 1 & 0.62 & 0.69 & Üst & 1 & 0 & 49 & 1 & 0.62 & 0.71 \\
\hline & Alt & 10 & 10 & 14 & 17 & & & Alt & 13 & 13 & 15 & 15 & & \\
\hline & Toplam & 63 & $58^{*}$ & 28 & 36 & & & Toplam & 63 & $58 *$ & 28 & 36 & & \\
\hline 11 & Üst & 17 & 32 & 5 & 7 & 0.31 & 0.36 & Üst & 13 & 29 & 3 & 6 & 0.31 & 0.40 \\
\hline & Alt & 21 & 9 & 9 & 13 & & & Alt & 22 & 10 & 11 & 13 & & \\
\hline & Toplam & 27 & $100 *$ & 20 & 37 & & & Toplam & 27 & $100 *$ & 20 & 37 & & \\
\hline 12 & Üst & 3 & 50 & 2 & 6 & 0.53 & 0.63 & Üst & 2 & 45 & 1 & 3 & 0.53 & 0.66 \\
\hline & Alt & 14 & 10 & 8 & 20 & & & Alt & 12 & 13 & 13 & 19 & & \\
\hline & Toplam & 52 & $87 *$ & 25 & 19 & & & Toplam & 52 & $87 *$ & 25 & 19 & & \\
\hline 13 & Üst & 13 & 44 & 2 & 1 & 0.46 & 0.46 & Üst & 9 & 38 & 2 & 1 & 0.46 & 0.52 \\
\hline & Alt & 18 & 14 & 13 & 7 & & & Alt & 21 & 13 & 15 & 8 & & \\
\hline 14 & Toplam & 22 & $100^{*}$ & 43 & 19 & & & Toplam & 22 & $100 *$ & 43 & 19 & & \\
\hline 14 & Üst & 2 & 51 & 8 & 0 & 0.53 & 0.60 & Üst & 1 & 48 & 2 & 0 & 0.53 & 0.72 \\
\hline & Alt & 13 & 13 & 17 & 9 & & & Alt & 11 & 13 & 22 & 10 & & \\
\hline & Toplam & 27 & 36 & $92 *$ & 28 & & & Toplam & 27 & 36 & $92 *$ & 28 & & \\
\hline 15 & Üst & 7 & 2 & 50 & 2 & 0.49 & 0.56 & Üst & 5 & 1 & 44 & 1 & 0.49 & 0.66 \\
\hline & Alt & 7 & 17 & 14 & 13 & & & Alt & 9 & 20 & 12 & 15 & & \\
\hline & Toplam & $102 *$ & 19 & 28 & 33 & & & Toplam & $102 *$ & 19 & 28 & 33 & & \\
\hline 16 & Üst & 49 & 1 & 7 & 4 & 0.54 & 0.54 & Üst & 42 & 1 & 5 & 3 & 0.54 & 0.54 \\
\hline & Alt & 14 & 9 & 11 & 17 & & & Alt & 17 & 9 & 11 & 18 & & \\
\hline & Toplam & 16 & $56^{*}$ & 47 & 54 & & & Toplam & 16 & $56^{*}$ & 47 & 54 & & \\
\hline 17 & Üst & 0 & 30 & 13 & 16 & 0.30 & 0.36 & Üst & 0 & 26 & 11 & 12 & 0.30 & 0.37 \\
\hline & Alt & 9 & 7 & 15 & 17 & & & Alt & 10 & 8 & 18 & 17 & & \\
\hline & Toplam & $68^{*}$ & 47 & 34 & 39 & & & & & & & & & \\
\hline Ç1 & Üst & 33 & 6 & 10 & 12 & 0.36 & 0.36 & & & & & & & \\
\hline & Alt & 10 & 18 & 12 & 14 & & & & & & & & & \\
\hline & Toplam & 16 & 51 & 34 & $85^{*}$ & & & & & & & & & \\
\hline Ç2 & Üst & 3 & 14 & 6 & 38 & 0.45 & 0.35 & & & & & & & \\
\hline & Alt & 7 & 16 & 15 & 15 & & & & & & & & & \\
\hline & Toplam & $37 *$ & 49 & 34 & 64 & & & & & & & & & \\
\hline Ç3 & Üst & 12 & 17 & 11 & 20 & 0.20 & -0.03 & & & & & & & \\
\hline & Alt & 12 & 12 & 11 & 19 & & & & & & & & & \\
\hline & Toplam & 27 & 23 & $33 *$ & 105 & & & & & & & & & \\
\hline Ç4 & Üst & 6 & 5 & 3 & 47 & 0.18 & -0.12 & & & & & & & \\
\hline & Alt & 14 & 13 & 9 & 18 & & & & & & & & & \\
\hline & Toplam & 27 & $86^{*}$ & 31 & 41 & & & & & & & & & \\
\hline Ç5 & Üst & 6 & 38 & 5 & 11 & 0.46 & 0.35 & & & & & & & \\
\hline & Alt & 11 & 15 & 15 & 12 & & & & & & & & & \\
\hline & Toplam & 22 & $65^{*}$ & 65 & 33 & & & & & & & & & \\
\hline Ç6 & Üst & 4 & 29 & 23 & 4 & 0.35 & 0.27 & & & & & & & \\
\hline & Alt & 6 & 11 & 17 & 18 & & & & & & & & & \\
\hline & Toplam & 16 & 6 & 34 & $131^{*}$ & & & & & & & & & \\
\hline Ç7 & Üst & 1 & 0 & 11 & 49 & 0.70 & 0.23 & & & & & & & \\
\hline & Alt & 7 & 2 & 13 & 31 & & & & & & & & & \\
\hline & Toplam & 37 & $56^{*}$ & 18 & 74 & & & & & & & & & \\
\hline Ç8 & Üst & 6 & 19 & 0 & 36 & 0.30 & 0.11 & & & & & & & \\
\hline & Alt & 17 & 11 & 10 & 14 & & & & & & & & & \\
\hline & Toplam & $78^{*}$ & 39 & 32 & 32 & & & & & & & & & \\
\hline Ç9 & Üst & 38 & 11 & 9 & 3 & 0.41 & 0.38 & & & & & & & \\
\hline & Alt & 13 & 18 & 10 & 10 & & & & & & & & & \\
\hline
\end{tabular}

* Maddenin doğru yanıt seçeneği. 


\section{Sonuçlar, Tartışma ve Öneriler}

Bu çalışma ile 2018 Fen Bilimleri Öğretim Programında yer alan altıncı sınıf ses ve özellikleri ünitesine yönelik öğrencilerin akademik başarılarını ölçmek için geçerli ve güvenilir bir ölçme aracı geliştirilmiştir. Geliştirilen bu test, toplamda 17 maddeden oluşmaktadır. Yenilenen Bloom taksonomisine (Anderson et al., 2001) göre testin son halinde yer alan 1., 7., 13. ve 14. soru olgusal bilgi-hatırlama türünde 3. soru kavramsal bilgi-hatırlama türünde 2., 4., 5., 6., 8., 9., 10., 11., 12., 15., 16. ve 17. soru kavramsal bilgi-anlama düzeyindedir. Bu durum ele alındığında testte yer alan soruların olgusal ve kavramsal bilgiyi ölçmeye yönelik olduğu ayrıca bilişsel süreç boyutu açısından hatırlama ve anlama düzeylerine göre olduğu görülmektedir. Gerek işlemsel ve üstbilişsel bilgiye gerekse uygulama, çözümleme, değerlendirme ve yaratma bilişsel süreçlerine yönelik sorular testte bulunmamaktadır.

Geliştirilen ölçeğin yapı geçerliği için tespit edilen uyum iyiliği değerleri incelendiğinde ki-kare/serbestlik derecesinin ( $\chi 2 / \mathrm{df}) 2.097$ olduğu tespit edilmiştir. Bu değerin 2 ile 3 arasında olması yapının kabul edilebilir durumda olduğunun bir göstergesi olarak yorumlanmaktadır (Şimşek, 2007). Ayrıca RMSEA, GFI, AGFI ve CFI uyum iyiliği değerlerinde ise RMSEA'nın 0.05-0.08 aralı̆̆ında olması, GFI ve AGFI'nın 0.90-0.95 ve CFI'nın 0.95-0.97 aralığında olması yapının iyi uyum iyiliği gösterdiğini ortaya koymaktadır (Thompson, 2000). Bu çalışmada testin son halinin tespit edilen RMSEA (0.0059), GFI (0.937), AGFI (0.928) ve CFI (0.966) değerleri testin iyi uyum iyiliği değerleri gösterdiğinin bir delili olarak yapı geçerliğini ortaya koymaktadır. Ayrıca faktör yüklerinin 0.340-0.719 arasında olması da maddelerin yapıya uygunluğunu göstermektedir (Kline, 1994).

Ölçme aracı geliştirme sürecinde yapılan madde analizleri neticesinde her bir maddenin güçlük, ayırt edicilik indeksi hesaplanmış, testin ortalama değerleri de ortaya konulmuştur. Maddelerin güçlük indeksleri 0.30 ile 0.69 arasında değişmekte iken ortalaması 0.471 olarak hesaplanmıştır. 0 ile 1 arasında değer alabilen madde güçlük indeksinin 1'e yaklaşması testin güçlüğünün azaldığı 0'a yaklaşması ise arttı̆ııı göstermektedir (Bayrakçeken, 2012; Turgut \& Baykul, 2012). Ayrıca başarı testlerinde ortalama güçlüğün de 0.50'lerde olması beklenmektedir (Baykul, 2000; Gömleksiz \& Erkan, 2010). Bu durum testin ortalama bir güçlüğe sahip olduğunu ortaya koymaktadır. Testte yer alan maddelerin ayırt edicilik indeksleri ise 0.36 ile 0.72 arasında değişmekte olup ortalaması 0.562 'dir. -1 ile +1 arasında değer alabilen ayırt edicilik indeksi; testin başarı düzeyi yüksek olan öğrencilerle, düşük olan öğrencileri birbirinden ayırıp ayıramadığını ortaya koymaktadır. Bu indeksin 0'a yaklaşması düşük bir ayırt ediciliği gösterirken +1 'e yaklaşması ise yüksek ayırt ediciliği göstermektedir (Bayrakçeken, 2012). Dolayısıyla testin ortalama ayırt edicilik indeksi testin, başarı düzeyi yüksek olan öğrencilerle düşük olan öğrencileri ayırt edebildiğini göstermektedir.

SÖBT'nin hesaplanan KR-20 güvenirlik katsayısı 0.785 olarak belirlenmiştir. Bu değer 0.60 ile 0.90 aralığında olduğundan dolayı testin sonuçlarının güvenilir bir yapıda olduğunu ortaya koymaktadır (Altunışık, Coşkun, Bayraktaroğlu, \& Yıldırım, 2007; Atılgan, Kan, \& Doğan, 2009). Alanyazın incelendiğinde ise ilgili konuya yönelik ortaya konulmuş ölçme araçlarının güvenirlik katsayılarının, bu çalışma ile ortaya konulan güvenirlik katsayısıyla birbirlerine yakın olduğu görülmektedir. Bu duruma örnek olarak Akarsu (2015) tarafından sekizinci sınıf öğrencilerinin ses ünitesine yönelik kavram düzeyinde bilgilerini ölçmek için geliştirdiği testinin güvenirlik katsayısı (0.72) ve Evrekli ve diğerlerinin (2012) altıncı sınıf ışık ve ses ünitesi ile ilgili yaptığı çalışmada başarı testinin güvenirlik katsayısı (0.80) verilebilir.

Son olarak geliştirilen bu başarı testinin hem ünite sonu değerlendirmede hem de bir üst eğitim seviyesindeki öğrencilerin ön bilgilerini yoklamada kullanılması önerilmektedir. Ayrıca testin geliştirme sürecinde her bir madde için yapılan analizlerle ortaya konulan güçlü çeldiricilerden yola çıkılarak öğrencilerin kavramsal anlamalarını ortaya çıkartılabilecek testlerin geliştirilmesi önerilmektedir.

Teşekkür Notu

Veri toplama sürecindeki önemli katkıları için Metin Şardağ’a teşekkür ederiz. 


\section{Kaynakça / References}

Akarsu, B. (2015). Ses kavram testi. Journal of Europen Education, 5(1), 23-30.

Akarsu, B. (2018). Ölçme ve değerlendirme (1. baskı). İstanbul: Cinius Yayınları.

Altunışık, R., Coşkun, R., Bayraktaroğlu, S., \& Yıldırım, E. (2005). Sosyal bilimlerde araştırma yöntemleri. Sakarya: Sakarya Kitabevi.

Anderson, L. W., Krathwohl, D. R., Airasian, P. W., Cruikshank, K. A., Mayer, R. E., Pintrich, P. R., Raths, J., Wittrock, M. C. (2001). A taxonomy for learning, teaching, and assessing: A revision of Bloom's Taxonomy of educational objectives. New York, NY: Longman.

Atılgan, H., Kan, A., \& Doğan, N. (2009). Eğitimde ölçme ve değerlendirme. Ankara: Anı Yayıncılık.

Aydın, A., \& Kömürkaraoğlu, S. (2016). Işık ve ses ünitesinin öğretiminde Jigsaw tekniğinin bilgilerin kalıcılık düzeylerine etkisinin incelenmesi ve bu teknik hakkında öğrenci görüşleri. Kastamonu Eğitim Dergisi, 24(1), 335-352.

Aytekin, A. (2018). Ortaokul 5. sınıf fen bilimleri dersi ışı̆̆ın ve sesin yayılması ünitesine yönelik geliştirilen materyal ve deney etkinliklerinin ögrenci akademik başarısı ve motivasyonuna etkisinin incelenmesi (Yayınlanmamış yüksek lisans tezi). Kocaeli Üniversitesi, Kocaeli.

Bakırcı, H., Çepni, S., \& Yıldız, M. (2015). Ortak bilgi yapılandırma modelinin altıncı sınıf öğrencilerinin akademik başarılarına etkisi: Işık ve ses ünitesi. Dicle Üniversitesi Ziya Gökalp Ĕ̈itim Fakültesi Dergisi, 26, 182-204.

Baykul, Y. (2000). Eğitimde ve psikolojide ölçme: Klasik test teorisi ve uygulaması. Ankara: ÖSYM Yayınları.

Bayrakçeken, S. (2012). Test geliştirme. E. Karip (Ed.), Ölçme ve değerlendirme (5. Bask1) içinde (ss. 294-324). Ankara: Pegem.

Bell, B., \& Cowie, B. (2002). Formative assessment and science education. New York, NY: Kluwer.

Büyükkara, S. (2011). Illkögretim 8. sınıf fen ve teknoloji dersi ses ünitesinin bilgisayar simülasyonları ve animasyonları ile ögretiminin ögrenci başarısı ve tutumu üzerine etkisi (Yayınlanmamış yüksek lisans tezi). Selçuk Üniversitesi, Konya.

Büyüköztürk, Ş. (2018). Sosyal bilimler için veri analizi el kitabı: Istatistik, araştırma deseni, SPSS uygulamaları ve yorum. Ankara: Pegem.

Calderon-Canales, E., Gallegos-Cazares, L., \& Flores-Camacho, F. (2019). Sound representations in preschool students. Infancia Y Aprendizaje, 42(4), 952-999.

Caleon, I., \& Subramaniam, R. (2010). Development and application of a three-tier diagnostic test to assess secondary students' understanding of waves. International journal of science education, 32(7), 939-961.

Calik, M., Okur, M., \& Taylor, N. (2011). A comparison of different conceptual change pedagogies employed within the topic of "Sound Propagation". Journal of Science Education and Technology, 20(6), 729-742.

Çalık, M., \& Ayas, A. (2003). Çözeltilerde kavram başarı testi hazırlama ve uygulama. Pamukkale Üniversitesi Eğitim Fakültesi Dergisi, 14(14), 1-17.

Demirci, N., \& Efe, S. (2007). İlköğretim öğrencilerinin ses konusundaki kavram yanılgılarının belirlenmesi. Necatibey Ĕ̆itim Fakültesi elektronik Fen ve Matematik Eğitimi Dergisi, 1(1), 23-56.

Dinçer, T., \& Özcan, Ö. (2016). Examining the mental models related to sound of pre-service physics teachers in different contexts. In SHS Web of Conferences (Vol. 26, p. 01118).

Eshach, H. (2014). Development of a student-centered instrument to assess middle school students' conceptual understanding of sound. Physical Review Special Topics-Physics education Research, 10(1), 010102.

Eshach, H., Lin, T. C., \& Tsai, C. C. (2018). Misconception of sound and conceptual change: A cross-sectional study on students' materialistic thinking of sound. Journal of Research in Science Teaching, 55(5), 664-684.

Evrekli, E., İnel, D., \& Balım, A. G. (2012). Kavram ve zihin haritası kullanımının öğrencilerin kavramları anlama düzeyleri ile fen ve teknolojiye yönelik tutumları üzerindeki etkileri. Abant İzzet Baysal Üniversitesi Ĕ̈itim Fakültesi Dergisi, 12(1), $229-250$. 
Fraenkel, J. R., Wallen, N. E., \& Hyun, H. H. (2012). How to design and evaluate research in education (8th ed.). New York, NY: McGraw-Hill.

Gömleksiz, M., \& Erkan, S. (2010). Eğitimde ölçme ve değerlendirme (2. baskı). Ankara: Nobel.

Gunhaart, A., \& Srisawasdi, N. (2012). Effect of integrated compute-based laboratory environment on students' physics conceptual learning of sound wave properties. Procedia-Social and Behavioral Sciences, 46, 5750-5755.

Hernández, M. I., Couso, D., \& Pintó, R. (2012). The analysis of students' conceptions as a support for designing a teaching/learning sequence on the acoustic properties of materials. Journal of Science Education and Technology, 21(6), 702-712.

Hrepic, Z., Zollman, D. \& Rebello, S. (2002). Identifying students' models of sound propagation. Access: https://csuepress.columbusstate.edu/bibliography_faculty/575/

Hrepic, Z., Nettles, C., \& Bonilla, C. (2013) Demonstrating sound wave propagation with candle flame and loudspeaker. The Physics Teacher, 5l(1), 16-19.

Iliaki, G., Velentzas, A., Michailidi, E., \& Stavrou, D. (2019). Exploring the music: a teaching-learning sequence about sound in authentic settings. Research in Science \& Technological Education, 37(2), 218-238.

Katz, L. J., \& Slomka, G. T. (1999). Achievement testing. In G. Goldstein \& M. Hersen (Eds.), Handbook of psychological assessment (pp. 149-182). Oxford: Pergamon.

Kistak, Ö. (2014). İlköğretim 8. sinıffen ve teknoloji dersi ses ünitesinin yaşam temelli yaklaşımla öğretimi (Yayınlanmamış yüksek lisans tezi). Balıkesir Üniversitesi, Balıkesir.

Kline, P. (1994). An easy guide to factor analysis. New York, NY: Routledge.

Korkmaz, H., \& Kaptan, F. (2005). Fen eğitiminde öğrencilerin gelişimini değerlendirmek için elektronik portfolyo kullanımı üzerine bir inceleme. The Turkish Online Journal of Educational Technology, 4(1), 101-106.

Lin, S. W. (2004). Development and application of a two-tier diagnostic test for high school students' understanding of flowering plant growth and development. International Journal of Science and Mathematics Education, 2(2), 175-199.

MEB. (2018). Fen bilimleri dersi öğretim programı (ilkokul ve ortaokul 3, 4, 5, 6, 7 ve 8. sinıflar). Ankara: Milli Eğitim Bakanlığı.

Metin, M. (2013). Öğretmenlerin performans görevlerini hazırlarken ve uygularken karşılaştığı sorunlar. Kuram ve Uygulamada Ĕ̈itim Bilimleri, 13(3), 1645-1673.

Newfields, T. (2006). Teacher development and assessment literacy. The proceedings of the 5th Annual JALT Pan-SIG Conference, Shizuoka, University College of Marine Science, Tokai.

Özcan, H., Koca, E., \& Söğüt, M. (2019). Ortaokul öğrencilerinin basınç kavramıyla ilgili anlayışlarını ölçmeye yönelik bir test geliştirme çalışması. Eğitim ve Toplum Araştırmaları Dergisi, 6(1), 130-144.

Pejuan, A., Bohigas, X., Jaén, X., \& Periago, C. (2012). Misconceptions about sound among engineering students. Journal of Science Education and Technology, 21(6), 669-685.

Romine, W. L., Schaffer, D. L., \& Barrow, L. (2015). Development and application of a novel rasch-based methodology for evaluating multi-tiered assessment instruments: Validation and utilization of an undergraduate diagnostic test of the water cycle. International Journal of Science Education, 37(16), 2740-2768.

Salgut, B. (2007). Illköğretim 5. sınıf fen ve teknoloji dersi lşık ve ses ünitesinde internetin de kullanıldı̆̆ bilgisayar destekli ögretimin ögrenci başarısına etkisi (Yayınlanmamış yüksek lisans tezi). Çukurova Üniversitesi, Adana.

Sözen, M., \& Bolat, M. (2014). 11-18 yaş öğrencilerin ses hızı ile ilgili sahip oldukları kavram yanılgılarının belirlenmesi. Ondokuz Mayıs Üniversitesi Eğitim Fakültesi Dergisi, 33(2), 505-523.

Şen, H. C., \& Eryılmaz, A. (2011). Bir başarı testi geliştirme çalışması: Basit elektrik devreleri başarı testi geçerlik ve güvenirlik araştırması. Yüzüncü Yll Üniversitesi, Eğitim Fakültesi Dergisi, 8(1), 1-39. 
Şenel-Çoruhlu, T., Er-Nas, S., \& Keleş, E. (2016). Beyin temelli öğrenme yaklaşımına dayalı web destekli öğretim materyalinin etkililiğinin değerlendirilmesi: Işık ve ses ünitesi. Amasya Üniversitesi Ĕ̆itim Fakültesi Dergisi, 5(1), 104-132.

Şimşek, Ö. F. (2007). Yapısal eşitlik modellemesine giriş: Temel ilkeler ve LISREL uygulamaları. Ankara: Ekinoks.

Teker, S. (2015). Fen bilimleri dersinde "Işı̆ğn ve sesin yayılması"” ünitesinin buluş yoluyla öğrenmeye göre işlenişinin ögrencilerin akademik başarısı ve tutumlarına etkisi (Yayınlanmamış yüksek lisans tezi). Ağrı İbrahim Çeçen Üniversitesi, Ağrı.

Tekindal, S. (Ed). (2017). Eğitimde ölçme ve değerlendirme. Ankara: Pegem.

Thompson, B. (2000). Ten commandments of structural equation modeling. In L. Grimm \& P. Yarnold (Eds.), Reading and understanding more multivariate statistics (pp. 261-284). Washington: DC: American Psychological Association.

Tok, Ş. (2008). Fen bilgisi dersinde yansıtıcı düşünme etkinliklerinin öğrencilerin akademik başarılarına ve fen bilgisi dersine yönelik tutumlarına etkisi. İlkögretim online, 7(3), 557-568.

Turgut, M., F., \& Baykul, Y. (2012). Eğitimde ölçme ve değerlendirme. Ankara: Pegem.

Volfson, A., Eshach, H., \& Ben-Abu, Y. (2018). Development of a diagnostic tool aimed at pinpointing undergraduate students' knowledge about sound and its implementation in simple acoustic apparatuses' analysis. Physical Review Physics Education Research, 14(2), 020127.

West, E., \& Wallin, A. (2013). Students' learning of a generalized theory of sound transmission from a teaching-learning sequence about sound, hearing and health. International Journal of Science Education 35(6), 980-1011.

Wild, T. A., Hilson, M. P., \& Hobson, S. M. (2013). The conceptual understanding of sound by students with visual impairments. Journal of Visual Impairment \& Blindness, 107(2), 107-116.

Yanar, S., Saylan-Kırmızıgül, A., \& Kaya, H. (2019). Development study of an achievement test regarding 6th grade light and sound subject. SDU International Journal of Educational Studies, 6(2), 53-72.

Yazıcıŏlu, S. (2017). Oyun temelli etkinliklerin ortaokul 6. sınıf öğrencilerinin akademik başarılarına, fen öğrenmeye yönelik motivasyonlarına ve tutumlarına etkisi: Işılk ve ses ünitesi örneği (Yayınlanmamış yüksek lisans tezi). Giresun Üniversitesi, Giresun.

Yılmaz, M. M. (2015). 8.sinıf öğrencilerinin ses konusundaki kavramlarla ilgili alternatif fikirlerinin incelenmesi (Yayınlanmamış yüksek lisans tezi). Balıkesir Üniversitesi, Balıkesir.

Yılmaz, T. (2016). Probleme dayalı öğrenme yönteminin fen konularının öğretilmesinde ortaokul 5. sinıf öğrencilerinin akademik başarılarına ve fen bilimleri dersine yönelik tutumlarına etkisi: Işılk ve ses (Yayınlanmamış yüksek lisans tezi). Bozok Üniversitesi, Yozgat.

Yurd, M., \& Olğun, Ö. S. (2008). Probleme dayalı öğrenme ve bil-iste-öğren stratejisinin kavram yanılgılarının giderilmesine etkisi. Hacettepe Üniversitesi Eğitim Fakültesi Dergisi, 35(35), 386-396.

Yüzbaşığlu, M. K. (2015). Ses konusuyla ilgili öğrenci zihinsel modellerin incelenmesi (Yayınlanmamış yüksek lisans tezi). Kastamonu Üniversitesi, Kastamonu. 
EK-1: Yenilenen Bloom Taksonomisine Göre Belirtke Tablosu

\begin{tabular}{|c|c|c|c|c|c|c|c|c|c|c|c|c|c|c|c|c|c|c|c|c|c|c|c|c|}
\hline Bilişsel Süreç Boyutu & \multicolumn{4}{|c|}{ Hatırlama } & \multicolumn{4}{|c|}{ Anlama } & \multicolumn{4}{|c|}{ Uygulama } & \multicolumn{4}{|c|}{ Çözümleme } & \multicolumn{4}{|c|}{ Değerlendirme } & \multicolumn{4}{|c|}{ Yaratma } \\
\hline $\begin{array}{ll}\text { Kazanımlar } & \text { Bilgi Boyutu } \\
\end{array}$ & ठै & $\underline{z}$ & 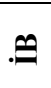 & $: \approx$ & ठै & $\underline{z}$ & $\mathscr{A}$ & $: ص$ & ठै & $\underline{\varepsilon}$ & $\stackrel{\theta}{\bullet}$ & $:$ ص & $\widetilde{0}$ & $\underline{\varepsilon}$ & $\triangleq$ & 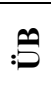 & ठै & $\underline{\varepsilon}$ & $\cong$ & 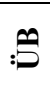 & ठै & 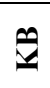 & $\mathscr{A}$ & : \\
\hline $\begin{array}{l}\text { F.6.5.1.1. Sesin yayılabildiği ortamları tahmin eder ve } \\
\text { tahminlerini test eder. }\end{array}$ & $\begin{array}{l}1, \\
14\end{array}$ & 3 & & & & Ç4 & & & & & & & & & & & & & & & & & & \\
\hline $\begin{array}{l}\text { F.6.5.2.1. Ses kaynağının değişmesiyle seslerin farklı } \\
\text { işitildiğini deneyerek keşfeder }\end{array}$ & & & & & & 5 & & & & & & & & & & & & & & & & & & \\
\hline $\begin{array}{l}\text { F.6.5.2.2. Sesin yayıldığ } 1 \text { ortamın değişmesiyle farklı } \\
\text { işitildiğini deneyerek keşfeder. } \\
\text { Frekans kavramına girilmez. }\end{array}$ & & & & & & 10 & & & & & & & & & & & & & & & & & & \\
\hline $\begin{array}{l}\text { F.6.5.3.1. Sesin farklı ortamlardaki süratini karşılaştırır. } \\
\text { a. Sesin boşlukta neden yayılmadığı belirtilir. } \\
\text { b. Işılk ve sesin havadaki sürati; şimşek, yıldırım ve gök } \\
\text { gürültüsü olayları üzerinden karşılaştırılır. } \\
\text { c. Sesin bir enerji türü olduğuna değinilir. }\end{array}$ & 7 & & & & & $\begin{array}{l}\text { Ç1, } \\
2, \\
\text { Ç5, } \\
4, \\
6, \\
9, \\
12, \\
\text { Ç8, } \\
\text { Ç7 }\end{array}$ & & & & & & & & Ç3 & & & & & & & & & & \\
\hline F.6.5.4.1. Sesin yansıma ve soğurulmasına örnekler verir. & & & & & & $\begin{array}{l}\text { Ç2, } \\
11 \\
17\end{array}$ & & & & & & & & & & & & & & & & & & \\
\hline $\begin{array}{l}\text { F.6.5.4.2. Sesin yayılmasını önlemeye yönelik tahminlerde } \\
\text { bulunur ve tahminlerini test eder. }\end{array}$ & & & & & & Ç6 & & & & & & & & & & & & & & & & & & \\
\hline $\begin{array}{l}\text { F.6.5.4.3. Ses yalıtımının önemini açıklar. } \\
\text { Ses yalıtımı için geliştirilen teknolojik ve mimari } \\
\text { uygulamalara değinilir. }\end{array}$ & 13 & & & & & $\begin{array}{l}8 \\
15\end{array}$ & & & & & & & & & & & & & & & & & & \\
\hline $\begin{array}{l}\text { F.6.5.4.4. Akustik uygulamalarına örnekler verir. } \\
\text { Modern ve kültürel mimarideki uygulamalara vurgu } \\
\text { yapılır. } \\
\text { Örneğin Süleymaniye Camii'nin akustik mimarisine atıf } \\
\text { yapılır. }\end{array}$ & Ç9 & & & & & 16 & & & & & & & & & & & & & & & & & & \\
\hline
\end{tabular}

OB: Olgusal Bilgi, KB: Kavramsal Bilgi, İB: İşlemsel Bilgi, ÜB: Üstbilişsel Bilgi 


\section{EK-2}

\section{SES VE ÖZELLIKKLERİ ÜNITTESİ BAŞARI TESTİ}

1) Masa üzerindeki dört radyo da açıtır. Buse hangisinin sesini kesinlikle duyamaz?

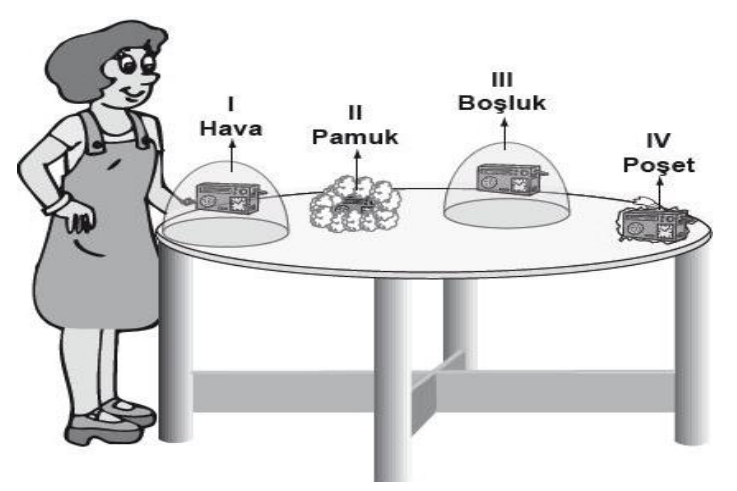
A) I
B) II
C) III
D) IV

2) Seda'nın sorduğu bir soru üzerine öğretmeni, "Örneğin aynı anda meydana gelmelerine rağmen gök gürültüsü, şimşeğin görülmesinden belli bir süre sonra duyulur." cevabını vermiştir.

\section{Buna göre, Seda'nın öğretmenine sorduğu soru aşağıdakilerden hangisidir?}
A) Işı̆̆ın ve sesin havadaki yayılma hızlarını karşılaştırabileceğimiz bir örnek verir misiniz?
B) Sesin veya 1şığın farklı ortamlardaki hızlarını karşılaştırabileceğimiz bir örnek verir misiniz?
C) Sesin ve 1şı̆̆ın yayıldığı ortamın yoğunluğuna bağlı olarak hızlarının değiştiğini gösteren bir örnek verir misiniz?
D) Işı̆̆ın ve sesin yansıması ile ilgili bir örnek verir misiniz? 
3) Murat, $\hat{\sim}, \square$ ve $\bigcirc$ sembolleriyle ifade ettiği ortamlarda sesin yayılıp yayılmayacağını tespit ederek, aşağıdaki tabloya kaydetti.

\begin{tabular}{|c|c|c|}
\hline \multirow{2}{*}{ Ortam } & \multicolumn{2}{|c|}{ Sesin Durumu } \\
\cline { 2 - 3 } & Yayıldı & Yayılmadı \\
\hline \multirow{2}{\imath}{} & $\sqrt{ }$ & \\
\hline$\square$ & & $\sqrt{ }$ \\
\hline$\bigcirc$ & $\sqrt{ }$ \\
\hline
\end{tabular}

Buna göre, sembollerle gösterilen ortamlar aşağıdakilerden hangisi olabilir?

\begin{tabular}{lcll} 
& \multirow{2}{*}{} & $\square$ & \\
\hline A) & Katı & Sıvı & Gaz \\
B) & Sıvı & Boşluk & Gaz \\
C) & Boşluk & Katı & Sıvı \\
D) & Sıvı & Boşluk & Boşluk
\end{tabular}

4) Ceren, iki taş parçasını aynı kuvvetle, önce havada sonra suda, kulağına aynı uzaklıkta tutarak birbirine vuruyor. Çıkan seslerin kulağına gelme sürelerinin aynı olmadığını fark ediyor.

\section{Buna göre Ceren yalnızca bu bilgilerden faydalanarak aşağıdaki sorulardan hangisine cevap verebilir?}
A) Farklı ortamlarda sesin yüksekliği değişir mi?
B) Farklı ortamlarda sesin yansıması değişir mi?
C) Farklı ortamlarda sesin frekansı değişir mi?
D) Farklı ortamlarda sesin hızı değişir mi?

5) Sesler kulağımıza çeşitli kaynaklardan ulaşır. Bir kuşun sesi ile bir kedinin sesi birbirinden farklıdır. Elektrikli süpürgeden çıkan ses ile duvarı delmek için kullanılan matkaptan çıkan sesler de birbirinden farklidir.

Yukarıda verilen örneklere göre bu farklılığın sebebi aşağıdakilerden hangisidir?
A) Ses kaynaklarının farklı olması
B) Sesin havada farklı yayılması
C) Havanın sesin yayılmasını engellemesi
D) Sesin yayılması için katı ortamın gerekli olması 
6 İçi boş karton bir borunun her iki ucuna balonlar geçirilerek bir davul yapıllyor. Davulun sağ tarafına vurulduğunda şekildeki gibi mum alevlerinin titreştiği gözlemleniyor.

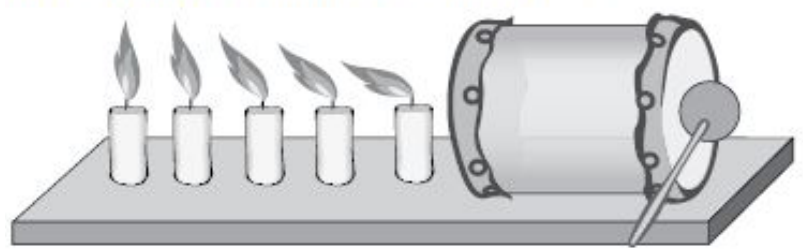

\section{Yalnızca bu gözlemlerden yararlanarak;}

I. Sesin bir enerji türü olduğu,

II. Sesin farklı ortamlardaki hızlarının farklı olduğu,

III. Ses düzeyinin, ses şiddetinden daima az olduğu

\section{yargılarından hangilerine ulaşılabilir?}
A) Yalnız I
B) I ve II
C) II ve III
D) I, II ve III

7) Sesin, $20^{\circ} \mathrm{C}^{\prime}$ ta farklı ortamlardaki yayılma hızları tabloda verilmiştir.

\begin{tabular}{|l|l|}
\hline Madde ortamı & Yayılma hızı (m/s) \\
\hline$K$ & 344 \\
\hline$L$ & 1463 \\
\hline$M$ & 5130 \\
\hline
\end{tabular}

Buna göre $K$, $L$ ve $M$ ortamları demir. su ve hava ortamlarından hangileri olabilir?

\begin{tabular}{llll} 
& $\mathrm{K}$ & $\mathrm{L}$ & $\mathrm{M}$ \\
\hline A) & Demir & $\mathrm{Su}$ & Hava \\
B) Hava & $\mathrm{Su}$ & Demir \\
C) Hava & Demir & $\mathrm{Su}$ \\
D) $\mathrm{Su}$ & Hava & Demir
\end{tabular}

8) I. Bina duvarlarını, içinde boşluklar bulunan tuğlalar ile yapmak

II. Gürültünün çok olduğu yaşam alanlarını ağaçlandırmak

III. Tiyatro ve sinema salonlarının duvarlarını yumuşak bir kumaş ile kaplamak Yukarıdakilerden hangileri ses yalıtımı için yapılmış olabilir?
A) I. ve II.
B) I. ve III.
C) II. ve III.
D) I, II. ve III. 
9) Kap içerisindeki suya davul yaklaştırılarak şekilde gösterildiği gibi tokmakla vuruluyor. Ortaya çıkan sesin etkisiyle suyun titreştiği gözleniyor.

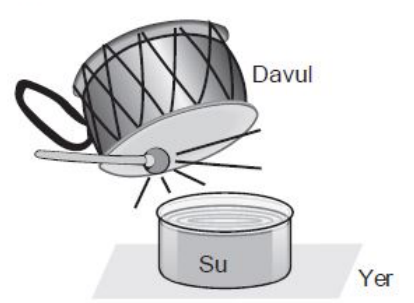

\section{Yalnızca bu gözlemden yola çıkılarak;}

I. Ses, katılarda sıvılara göre daha hızlı yayılır.

II. Ses bir enerji türüdür.

III. Ses, maddesiz ortamda yayılmaz.

\section{yargılarından hangilerine ulaşılabilir?}
A) Yalnız I.
B) Yalnız II.
C) I ve III.
D) I, II ve III.

10) Bir öğrenci iki elindeki birer taşla deney yapıyor.

- Taşları havada birbirine vuruyor.

- Daha sonra su dolu havuza tamamen dalarak taşları suyun içinde aynı şekilde birbirine vuruyor.

\section{Öğrenci bu deneyde sesle ilgili hangi konuyu araştırmaktadır?}
A) Sesin katı ortamlarda nasıl yayıldığ 1
B) Farklı cisimlerle üretilen sesin nasıl duyulduğu
C) Aynı sesin farklı ortamlarda nasıl duyulduğu
D)Farklı ses kaynağından çıkan sesin farklı yönlere nasıl yayıldığı

11) I. Tıpta ultrason cihazı kullanılarak iç organların görüntülenmesi

II. Sonar cihazı kullanılarak engellerin yerlerinin tespiti

III. Bina duvarları yapılırken içine strafor (köpük) gibi ses yalıtım malzemelerinin konulmas1

Yukarıdaki uygulamaların hangilerinde sesin yansımasından yararlanılmıştır?
A) Yalnız III
B) I ve II
C) II ve III
D) I, II ve III 
12) Neşe, bir parça gazete kâğıdını alıp üzerine bir miktar tuz döküyor. Bu kâğıdı hoparlörün üzerine koyarak müziğin sesini arttırıyor. Ses arttıkça tuz taneciklerinin bu gazete kâğıdı üzerinde hareket ettiğini gözlemliyor.

\section{Neşe, yalnızca bu gözleminden hareketle aşağıdaki yargılardan hangisine ulaşabilir?}
A) Ses boşlukta yayılmaz.
B) Ses başka bir enerji türüne dönüşebilir.
C) Sesin yayılma sürati sıvı ortamlarda gaz ortamlara göre daha fazladır.
D) Sesin yayılma sürati katı ortamlarda sıvı ortamlara göre daha fazladır.

13) Müzik çalmakta olan bir radyo, şekildeki gibi her tarafı kapalı bir ev modeli içine konulduğunda sesi dışarıdan duyulabiliyor.

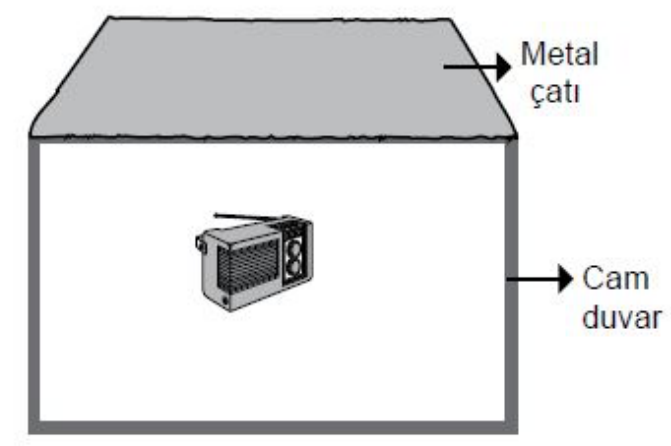

Bu ev modelinde çatı ve duvarda aynı şekilde hangi malzemeler kullanılırsa ses dışarıdan daha az duyulur?
Çatı
Duvar
A) Cam
Metal
B) Cam yünü
Sünger
C) Metal
Ayna
D) İnce kâğıt
Metal

14) Bilim insanları, Güneş'te oluşan patlamaların ışı̆̆ını gözleyebilirken patlamalarda ortaya çıkan sesleri duyamamaktadırlar.

\section{Bu durumun nedeni aşağıdakilerden hangisidir?}
A) Ses bütün katılarda yayılırken 1şık bazı katılarda yayılır.
B) Sesin yayılabilmesi için maddesel ortama ihtiyaç vardır.
C) Işık, sesten daha süratli yayılır.
D) Ses bir enerji türüdür. 
15) Bir şehirde taşıtların geçtiği gürültülü yol kenarlarına camdan duvar yapılıyor.

Bu uygulama ile aşağıdakilerden hangisi gerçekleştirilmiştir?
A) Sesin her tarafa daha çabuk yayılması
B) Sesin daha geniş alanlara yayılması
C) Sesin soğrulması ve yansıması
D) Ses enerjisinin artırılmas1

16) Boş ve büyük bir odada bulunan Ali, annesine "Anneciğim!" diye bağırdı. Bir süre sonra kendi sesinin tekrarladığını fark etti.

Buna göre Ali, yalnızca bu olaydan yola çıkarak aşağıdakilerden hangisine ulaşır?
A) Engelle karşılaşan ses yansır.
B) Ses kaynaktan uzaklaştıkça daha az duyulur.
C) Ses maddesel ortamda soğurulur.
D) Ses farklı ortamlarda farklı soğurulur.

17) Sesin yansıması ve yankı olayları, yaşamımızda önemli bir yer tutar. Bunlara birçok örnek verilebilir.

I- Doktorların ultrason cihazı kullanarak hastalık teşhisi yapmaları,

II- Gemilerin sonar cihazı kullanarak yön ve derinlik tespiti yapmaları,

III- Tiyatro salonlarının duvar ve tavanlarının yumuşak ve pürüzlü yüzey ile kaplanması. Yukarıda verilen örneklerden hangileri, bilim ve teknolojide sesin yansımasından yararlanıldığını gösterir?
A) Yalnız I
B) I ve II
C) II ve III
D) I, II ve III 
EK-3: Çıkartılan Maddeler

Çıkartılan 1) Şekildeki gibi bölmelendirilmiş dairesel bir odada farklı ortamlar bulunmaktadir.

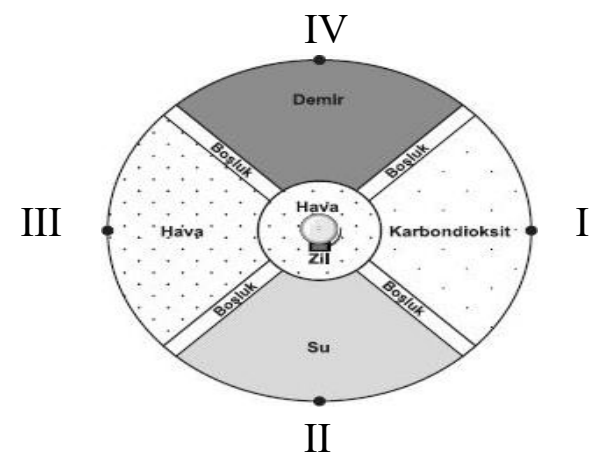

Ortamların yoğunluk sıralaması demir $>$ su $>$ hava $>$ karbondioksit olduğuna göre, odanın merkezinde çalan zilin sesi en geç hangi noktadan duyulur?
A) I
B) II
C) III
D) IV

Çıkartılan 2) Bir öğretmen, Fen ve Teknoloji dersinde, öğrencilerden sesin yansımasına örnekler vermelerini istiyor. Öğrenciler aşağıdaki örnekleri veriyorlar:

Kemal: "Doktorların, ultrason cihazı kullanarak iç organlarımızı görmeleri"

Ahmet: "Balıkçıların, sonar cihazı kullanarak balık avlamaları"

Sema: "Kar yağdığında, sokağımızın diğer günlerden daha sessiz olması"

Özlem: "Derin bir vadi kenarında bağırdı̆̆ımızda, sesimizin yankı yapması"

Buna göre, hangi öğrencilerin verdiği örnekler sesin yansıması ile ilgili olabilir?
A) Kemal, Ahmet ve Sema
B) Ahmet, Sema ve Özlem
C) Kemal, Sema ve Özlem
D) Kemal, Ahmet ve Özlem 
Çıkartılan 3) Sesle ilgili bir bilgi için modelleme yapan Emin, 300 adet domino taşından 100 'erli üç grup yapıyor. Birinci gruptaki taşları $1 \mathrm{~cm}$, ikinci gruptaki taşları $1,5 \mathrm{~cm}$ ve üçüncü gruptaki taşları $2 \mathrm{~cm}$ arayla şekildeki gibi diziyor.

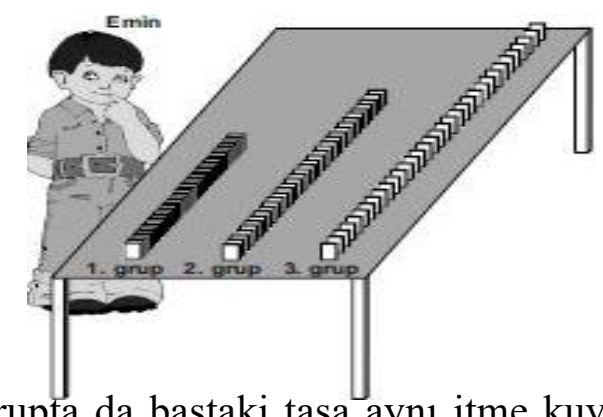

Üç grupta da baştaki taşa aynı itme kuvvetini uygulayan Emin, son taş düşen kadar geçen süreyi aşağıdaki tabloya kaydediyor.

Emin'in ölçüm sonuçları:

\begin{tabular}{|l|l|}
\hline Grup & Geçen Süre \\
\hline 1. Grup & 2 saniye \\
\hline 2. Grup & 2,5 saniye \\
\hline 3. Grup & 3 saniye \\
\hline
\end{tabular}

Buna göre Emin, hangi bilgi için modelleme yapmıştır?

A) Ses en hizlı katılarda, sonra sirasiyla sivı ve gazlarda yaydır.

B) Sesin şiddeti artsa da yayılma hızı değişmez.

C) Ses bir enerjidir ve başka bir enerjiye dönüşebilir.

D) Ses enerjisi kaynağa yaklaştıkça büyür.

Çıkartılan 4) Mete, iki taşı havada ve su içinde birbirine vurarak, çıkan sesleri dinledi. Daha sonra evin kapısına kulağını dayadı ve kapıya eliyle vurarak, yine çıkan sesi dinledi.

Mete'nin yukarıda yaptığı etkinlikten yola çıkarak;

I- Ses, boşlukta yayılır mı?

II- Ses, siv1 ve gaz ortamlarında yayılır mı?

III- Ses, katı ortamlarda yayılır mı?

Sorularından hangisine cevap bulunabilir?
A) Yalniz I' e
B) Yalnız II' ye
C) I ve II' ye
D) II ve III' e

Çıkartılan 5) Öğretmen sınıfta ses enerjisi ile ilgili aşağıdaki örnekleri verdi.

I- Jet uçaklarının geçişi sırasında çıkardıkları sesin pencere camlarını titreştirmesi

II- Bazı sanatçıların çıkardıkları ses ile bardağı kırması

III- Ellerimizi birbirine vurduğumuzda ses çıkması

Buna göre, öğretmenin verdiği örneklerin hangilerinde ses enerjisi, başka bir enerjiye dönüşmüştür?
A) Yalniz I
B) I ve II
C) II ve III
D) I, II ve III 
Çıkartılan 6) Sevim, evinin önündeki caddeden geçen bir arabanın korna sesinden rahatsız olur. Daha sonra kulaklarına pamuk tıkayarak biraz rahatlar.

\section{Sevim'in rahatlaması,}

I. Sesin her yerde yayılması

II. Sesin farklı ortamda farklı yayılması

III. Sesin kaynağının farklılaşması sonucu, sesin de farklılaşması

ifadelerinden hangileri ile açıklanabilir?
A) Yalnız I.
B) Yalnız II.
C) Yalnız III.
D) I. ve III.

Çıkartılan 7) Sesin üç farklı ortamda yayılma hızları grafikte verilmiştir.

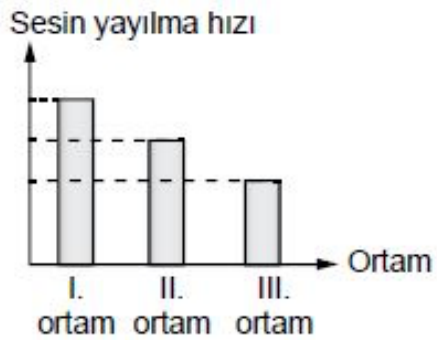

Buna göre, taneciklerinin büyüklükleri aynı olan bu ortamların, birim alandaki tanecik modelleri aşağıdakilerden hangisi gibi olabilir?

A)

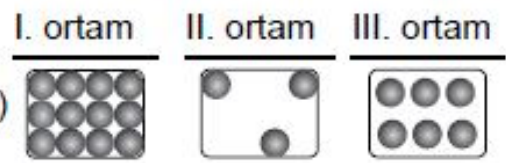

B)

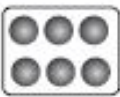

C)

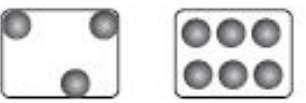

D)
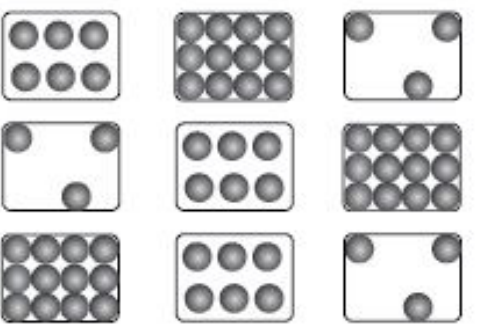
Çıkartılan 8 (21) Şekildeki gibi farklı maddeler boşluk ile birbirinden ayrılmıştır. Kürenin ortasına bir çalar saat konulduğunda, küre yüzeyi üzerindeki I, II ve III. noktalardan çalar saatin sesi duyulmuştur.

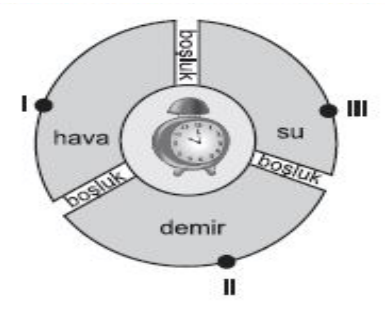

Saat çalmaya başladığında I. II ve III. noktalara sesin ulaşma süreleri aşağıdaki grafiklerin hangisinde doğru gösterilmiştir?

A) Sesin ulașma sūresi

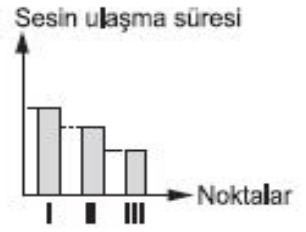

C) Sesin ulașma süresi

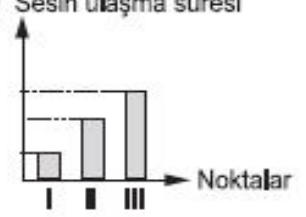

B) Sesin ulaşma süresi

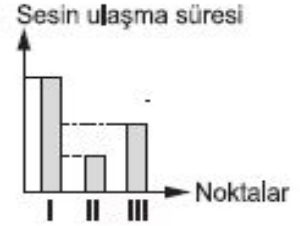

D) Sesin ulaşma süresi

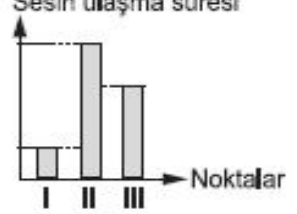

Çıkartılan 9) Kapalı alanda yankı oluşumunu önlemek için, bu alanların iç yüzeyi nasıl bir madde ile kaplanmalıdır?
A) Yumuşak ve pürüzlü
B) Yumuşak ve pürüzsüz
C) Sert ve pürüzlü
D) Sert ve pürüzsüz 